\title{
Higher education and the public good: Creating inclusive and diverse national universities in Indonesia in the era of globalization
}

\author{
Chiara Logli, University of Hawaii at Manoa
}

This chapter examines the tensions in the dynamics between public good purposes and provisions in the context of Indonesian national universities in the era of globalization. The focus is on how universities can represent and contribute to a diverse society while also aiming to be world-class institutions. I approach the concept of public good in terms of ultimate aspirations for the future, such as the development of citizenry and leadership in support of social improvement across the nation. I go on to relate public good to tangible means in the present, including educational legislative mandates, university regulations, coursework content, pedagogical strategies, and campus life.

Three research questions guide this inquiry. First, what are the aims of Indonesian national universities in terms of public good in the era of globalization? Second, what are the initiatives through which Indonesian national universities attempt to reach those goals? Third, how are those public good purposes and provisions challenging the globally prevailing education paradigm? I examine both national regulations and the case of the Universitas Gadjah Mada (UGM), one of the three top universities in Indonesia and a leading institution in educational reform.

From a disciplinary standpoint this study is relevant in that it illuminates how universities in multicultural societies can respond to globalization by being hybrid institutions, with local, 
national, and international allegiances to public good. From a theoretical perspective, it applies grounded cosmopolitanism to the study of an institution, rather than individuals. From a geographical stance, it expands the discourse on diversity in education beyond the dominant Anglo-American axis, by bringing attention to a majority-Muslim, Southeast Asian "developing" country like Indonesia, which has received relatively little academic notice compared to other Asian nations.

The geographic and demographic heterogeneity in Indonesia intensifies the complex interdependence between diversity and matters of access, equity, and capacity, as well as internationalization in higher education. Indonesia has an exceptionally diversified population with over 375 ethnic groups, 700 languages, six officially recognized creeds (i.e., Islam, Protestantism, Catholicism, Hinduism, Buddhism, and Confucianism), the greatest number of Muslim adherents in the world, and the fourth national highest population on the planet (i.e., 237 million people) scattered across 6,000 inhabited islands (Ananta 2013, Indonesian Central Agency on Statistics 2010). Regionality is impactful since origin generally determines ethnicity and religion (Aspinall 2009).

Tensions arise as Islam accounts for 87 percent of Indonesians and the Javanese ethnicity—which is almost entirely Muslim — constitutes 40 percent of the inhabitants, while wielding the majority of political power. Java — and Islam-centered policies have especially been condemned, as they affect political representation, economic development, and all various components of social organization, including the educational system. Despite these dichotomies, each ethno-religious community is highly heterogeneous, with different practices, doctrinal beliefs, political viewpoints, and regional variations. 


\section{Grounded and cosmopolitan allegiances in higher education}

This first section aims at drawing out theoretical insights regarding education as a public good in a world of interdependence where cultural diversity itself emerges as a key resource for responding to globalization. Education remains a public good, despite the criticisms for not being good enough (Hershock, Mason, and Hawkins 2007). The meanings of both public good and good education have been contested for centuries, within and across national boundaries. A good education is generally perceived as contributing to personal character and capabilities as well as (more recently) national development. According to the leading schools of thought, education entails knowledge production, socialization, and the flourishing of the whole human being (Rizvi 2007). It is associated with democratic equality, social mobility, and national efficiency.

Educational aims have been framed through various lenses. Analytical approaches tend to be universalistic and ahistorical. By contrast, functionalist traditions are mainly instrumental and specific to the socio-political formations of a given society. More recent scholarly developments have cut across the binaries humanist and particular, ideal and material. For instance, the framework of the "social imaginary" requires the analysis of educational goals in terms of the norms that shape them as well as the practices that illustrate them. In other words, educational objectives rest on the "policies and programs that are derived from them," but also on "the context which provides them with meaning and legitimacy" (Rizvi 2007, 68).

With regard to context, the theory of grounded cosmopolitanism emphasizes the simultaneous impact of local, national, and international allegiances in the era of globalization (Kahn 2004). The concept of hybridity has been used to describe individuals' identities and I borrow it to examine institutions (Logli in press). In fact, each university holds both grounded 
(i.e., local and national) and cosmopolitan (i.e., humanist and global) affiliations. Similarly to a person, a college campus is "an ambivalent and complex third space of cultural practice, in which new authority structures pull [it] towards different narratives of identity" (Nilan and Feixa 2006, 108). Universities also possess "nomadic trajectories," namely polymorphous qualities that travel between "imaginaries of the national and logics of the trans(national)" (Harvey 2007, 273). They embody the tensions that emerge from local experiences being "saturated into global popular culture, capitalist consumption, media and technological networks, and the flows of human creativity, labor, thought and emotion" (Khoo 2008, 232).

Grounded and cosmopolitan references can appear in many forms and compositions in each university. Some institutions may be more concerned about preserving primordial cultures or nationalistic values than promoting universalist principles or global skills. Regardless of the specific shapes and proportions, grounded and cosmopolitan characteristics coexist; they are not perceived as oppositional, but rather overlapping and compatible. Global influences transform in local traditions, locality is assimilated into globality, and a hybrid realm of new meanings emerges. Hybridization offers universities a place to construct alternative identities.

The literature on higher education provides insightful commentaries on the interconnectedness between grounded and cosmopolitan characteristics within universities in the Asia Pacific. Hawkins recognizes "the existence of multiple and often interleaving educational paradigms - highly variable patterns of educational practice that are tied in many and intimate ways to specific local-national-regional conditions" $(2007,138)$. Yet, these grounded formations do not arise autonomously; they are intertwined with global influences. Hershock also stresses that "education is positioned not only to be affected by, but also to affect local, national, regional 
and global social, economic, political, cultural and technological dynamics" (Hershock 2010, 1314).

In terms of grounded belongings, Hershock, Mason, and Hawkins agree that globalization has increased both uniformity and fragmentation in societies world-wide (2007). On one hand, contemporary globalization processes have led to "homogenizing linkages among local, national, regional and global 'flows' of goods, services, people, ideas and ideals" (Hershock 2010, 2). The world has become increasingly interconnected, with people coming together, physically and virtually, on the common premises of language use and technological communication systems (Ordonez 2007).

On the other hand, individuals who participate in global experiments are also heterogeneous, rather than homogenous. For example, separatist ethnic movements, religious resurgence, and gaps in social class have risen (Hershock 2010). Hershock, Mason, and Hawkins note that "globalization has come to involve an accentuation of difference-whether as something to be ignored (we are all equal, the appeal to universalism) or celebrated (we are all distinct or unique, the appeal to particularity)" (2007, 2). In Hershock's words, "globalization is not only an intensifier of interdependence, it is a multiplier and magnifier of differences" (2010, 2).

Within education, the increased emphasis on both the universal and the unique has brought into the foreground issues of difference, especially in terms of gender, ethnicity, religion, and social class but also learning styles and cultural norms (Hershock, Mason, and Hawkins 2007, Hershock 2010). These matters gain more weight in the context of increasing demand for higher education and limited capacity (Hawkins 2011). Hawkins points out concerns 
of access, survival, output, and outcome that relate to diversified student populations (2011). His intuitions echo Farrell's model on underrepresented students' probability of getting into college, completing their degree, learning the same knowledge and living relatively similarly postgraduation lives compared to students who more traditionally attend higher education (2007). Hawkins stresses that "regional disparities of certain population groups may hinge on structural, political or ethnic issues as certain groups occupy 'marginal lands' and find their opportunities for entrance to higher education are also marginalized" $(2011,25)$.

Hershock expands the lens of analysis on diversity $(2010,2012)$. He calls for an education that takes deep account of diversity as "a qualitative index of self-sustaining and difference-enriching patterns of mutual contribution to shared welfare” (Hershock 2010, 11). Differently stated, diversity indexes "the extent to which differences are activated as the basis of meaningful contribution to sustainably shared flourishing" (Hershock 2012, 44). Diversity is a function of complex, interdependent, and diversified modalities of interaction. It is a relational achievement that emerges over time; it "cannot be either mandated or expected to happen simply as a matter of course" (Hershock 2012,44). By contrast, variety is "a quantitative index of simple multiplicity that connotes things simply being-different” (Hershock 2010, 11). To clarify the distinction, Hershock compares zoos to ecosystems. Zoos are high in variety and their variety can be externally imposed. Ecosystems are high in diversity and their diversity can only rise from within.

University campuses can host a variety of student populations, program offerings, and types of institutions and partnerships among them while remaining "nothing more than factual co-existence" (Hershock 2010, 12). Hershock proposes that the realization of cultural diversity 
requires making differences meaningful and appreciating (i.e., valuing and adding-value-to) differences as the basis for mutual contribution. Educating for diversity is focused on "discerning how most effectively and sustainably to enable the differences of each to make a difference for all" (Hershock 2010, 19). It means "shifting the locus of concern from how much we differ-from each other to how we might best differ-for one another" (Hershock 2010, 18).

With regards to global affiliations, studies of higher education reveal a globally dominant paradigm. It is neo-liberal model (Rizvi 2007) of "grammar of schooling," in which universities attempt to emulate institutions in the West (Hawkins 2007, 137). It is also limited to passive modes of knowledge transmission (Neubauer 2007) and curriculum-based as well as competence-biased (Hershock 2007, 115). Market-driven dynamics have compromised all other human concerns, including matters of access, equity, and representation (Rizvi 2007). Yet, scholars argue that globalization does not necessarily have to follow the existent prevailing paradigm.

Rizvi proposes a form of globalization that is rooted in democratic traditions, rather than in the logic of the market (2007). This alternative approach generates an education that "expands the general welfare of communities" and "contributes to both public and private goods, to both social and economic ends, and to both national and global concerns." In particular, he advocates for an education that promotes cross-cultural and transnational dialogue, local and global thinking, as well as problem solving for humanity as a whole.

In terms of humanist references, Mason suggests an education that is based upon ethical universality, namely shared principles that reach across cultures (2007). He finds that multiculturalism provides transcultural ethics, such as the core value of respect for each other as 
persons and its ramifications into equal liberty, justice as fairness, and the fostering critical judgement in education. He concludes that only culturally-specific practices that are consistent with the principles of multiculturalism itself should be accepted. As a result, he is in favor of an education for multicultural ethics and a global, rather than a national, citizenship. This position is in line with Hershock's call for diversity in education that I have presented earlier $(2010,2012)$.

\section{Indonesian compliance to the globally dominant paradigm}

Scholarly reports have given ample space to the influence of the prevailing dominant paradigm on Indonesian higher education. Neoliberalism appears through government's low financial support, high content control, and a variety-based, rather than diversity-based, approach to cultural differences.

Indonesian higher education has made remarkable advancements in its relatively young life (Buchori and Malik 2004, Cummings and Kasenda 1989, Nizam 2006). Indonesia currently has one of the largest higher education systems in the world, with over 2,800 institutions serving four million students. Of the total institutions, approximately 95 percent are private and enroll 60 percent of the total students. The number of university students has increased from 200 in 1938 to almost 5 million in 2009. Recognizing that education leads to better employment opportunities, parents and youth value the college experience as an avenue to social mobility and economic gains.

The massification of higher education has brought tremendous challenges in providing satisfactory access and quality across the archipelago. Indonesia has one of the lowest expenditures on education as a percentage of GDP among low-income countries (Hawkins 2011). The public sector support for higher education is between $80-90$ percent of public 
university budgets; yet, it is still insufficient compared to the needs of the universities and students. Since 1999 a higher education autonomy policy has allowed universities to set and collect tuition fees. Yet, the provincial policy continues to be centralistic, while autonomy regulations lack clarity and generate confusion for all parts involved (Sunarto, Heng, and Saifuddin 2004).

Every year, more than 450,000 high school graduates take the entrance examination to compete for 75,000 seats in public universities (Buchori and Malik 2004). Less than 21 percent of Indonesian college-age population is enrolled in higher education and 74 percent of all university students are clustered on the island of Java, where the majority of universities and all premier institutions are concentrated. Students from urban areas are half in number than students from rural areas (Hawkins 2011). Students from low-income social classes are 20 percent compared to high-income populations.

Indonesian scholars clarify issues of access and quality as they relate to underrepresented students (Sunarto, Heng, and Saifuddin 2004). Across the archipelago, parents want education for their children, but are also reluctant to send them far away to an education that is disconnected from local realities and real-life skills. Indonesian education has generally adopted an accommodative or selective form of multiculturalism, meaning that the Javanese Muslim culture remains dominant but makes some provisions for the needs of minority groups. The central government in Jakarta determines educational reforms, which are then disseminated in a top-down manner through the use of homogenous standards, mainstream curricula, and centralized instructional materials. For instance, classes on civic and religious education are compulsory from kindergarten to college. Students can only study their own religion and 
institutions are required to provide religious teachers in accordance with students' faith (e.g., Hindu course by Hindu teachers for Hindu students) (Parker 2010). In academia, ethnocentric interpretations of culture remain prominent (Heryanto 1998). In recent years, universities have also turned into a breeding area for underground extremist Islamic networks (Fox 2004). Strict movements have spread across campus organizations, like KAMMI, which prescribe intensive training to lead to a personal transformation as "complete" or "total" Muslims.

My empirical findings confirmed these issues of geographical and financial disparities (Logli 2015). At UGM, around 5 percent of the undergraduate applicants are admitted for a total of 7,612 BA and BS students in 2011. UGM tuition and living expenses are cheaper than other public universities, but they are still out of reach for the majority of Indonesian youth who have to travel afar. Around $18 \%$ of the students receive free tuition based on both financial need, academic merit, and extra-curricular activities. Scholarships are supported by local governments, corporations, and private businesses as well as programs that generate income.

The national examination determines university access based on scholastic merit, according to the Ministry of Education. Yet, the quality of K-12 education is greater in Java than in other islands, so pupils do not have an equal chance to thrive in the national exam. For instance, in Eastern Indonesia, social services are especially scarce and families increasingly send their children to boarding schools or pre-college preparation institutes in Java, in order to enhance their opportunity to enter public universities. Most universities, and all top institutions, are also found in Java, but the Ministry of Education does not provide adequate scholarships for students to relocate and cover all college expenses. As a result of standardized policies and dearth of investments in education, the student body in public universities is facing an 
overrepresentation of students from Java and higher social classes. The growing homogeneity among students also increases homogeneity among faculty and executives, who are predominantly alumni.

The national curriculum limits students' hybridity, especially in terms of religious, civic, and academic preparation as well as character building. The mandatory monoreligious education divides students according to their own dogma and restrict their knowledge about other creeds. It is sometimes based on exclusivist theologies, which generate the disruptive beliefs that other creeds are false and inferior; consequently, a sense of self-identity is forged in opposition to the broader society. The compulsory course on citizenship is distant and irrelevant from students' contextual realities. It is a collection of historic and legal clauses, rather than a discussion on what diversity mean and how they are embodied in students' life. Overall, pedagogy remains teacher-center and some professors infiltrate teachings with their personal religious beliefs. In addition, since high-school, national tracks divide students between social and natural sciences. As a result, STEM students tend to lack broader understanding and perceive character building as unrelated to their studies.

Exclusivist Islamic factions recruit and organize on public campuses; their members are relatively limited in number but disproportionally influential, due to their means of action (e.g., street protests and threats of violence). The government inaction towards fundamentalist Islamic movements contributes to stabilize the rhetoric that religious extremism is ordinary and inevitable. Islamic hardliners jeopardize academic freedom and multicultural inclusiveness, as in the case of the lesbian Muslim scholar Irshad Manji's presentation, which was cancelled due to security reasons in 2012 . 


\section{Indonesian characteristics for a paradigm shift}

This section aims to provide a perspective on how Indonesian higher education is challenging the globally dominant paradigm. I add my empirical findings to the limited testimonies from the literature. I focus on the purposes and provisions that are entrenched in local, national, and international memberships. I view these hybrid approaches as manners to contest the prevailing paradigm. Rather than unconditionally following extrinsic directions, universities integrate global trends with primordial, national, and humanist principles.

Indonesian scholars have reported on recent efforts to increase diversity on campuses (Sunarto, Heng, and Saifuddin 2004). Some professors approach multicultural education as an instrument to teach ethics through the values of tolerance, democracy, and pluralism. Others present multiculturalism through the critical perspective of cultural studies, in order to address the difficulties in unlearning cultural biases and intergroup prejudices. Universities organize workshops and seminars on diversity involving a broad network of educators and community leaders.

UGM vision is "to be an excellent and innovative world class university, imbued with nation's cultural values based on Pancasila as the state ideology and dedicated to the nation's interest and humanity" (retrieved from http://ugm.ac.id/en/). In particular, UGM has five aspirations, namely being a university that is national, based on the Pancasila, serving all the people of Indonesia, preserving cultures, and becoming a world-class research institution.

UGM is the first public university built by Indonesian people at the time of independence from the Dutch colony. It was envisioned as a "miniature of Indonesia," with students from all religions, ethnicities, and provinces. UGM was founded to foster both knowledge and the five 
principles of the Pancasila (i.e., belief if one God, internationalism or humanitarianism, national unity, democracy based on deliberation as well as consensus, and social justice). Pancasila is viewed as a basis for universal ethics, which ties to the next mission. UGM is the university of the people, or of the struggle, because its goal is to prepare the leaders who can improve the country and the world. Academics and character building are equally important, in order to develop leaders who "care for the marginalized" and "give to society." UGM is the cultural university because of its location in Yogyakarta, often referred to as the capital of both tolerance and highest Javanese culture. Yogyakarta is considered an exceptional and exemplary city of inclusiveness, pluralism and anti-religious extremism. I have visited places of worship, schools, and events where participants of various ethno-religious backgrounds converge to study, pray, or dialogue, including a pesantren (Islamic boarding school) for transgendered students.

The aspiration towards internationalization is not only part of the Pancasila, but of UGM mission itself. The openness towards global influences is accompanied by the aim to preserve local and national allegiances. UGM incorporates grounded (i.e., primordial and national) and cosmopolitan (i.e., universalist and global) affiliations through various provisions.

UGM has succeeded in influencing recent governmental reforms. The ministry has adjusted its policies in order to reflect both domestic and international needs. The national law Number 12 Year 2012 prescribes that all public universities should pay special attention to students from the lower economic status as well as foreign countries. The law also indicates that other criteria for admissions can be considered in addition to the national examination scores. Over the decades, the government has expanded the number of new universities across the archipelago, although their number and quality are not comparable to the institutions in Java. The 
state has also been considering a reform of the law on civil servants, which would facilitate the hiring and promotion of the faculty, based on both credentials and background.

Prior to the 2012 law, UGM utilized a variety of instruments for admissions to prioritize both merit and differentiated backgrounds. Since its establishment in 1949, UGM has been a pioneer institution in creating "affirmative actions" to recruit qualified students across the archipelago, despite governmental demands for standardized admissions and inadequate financial support. For example, in early 2000s, UGM employed both national examination and an ad hoc "UGM exam." Upon pressure by the ministry, in 2011 UGM stopped its ad hoc exam, but replaced it with an "invitation" process, since the central government did not allow to use the term "selection." Half of the students are admitted through national examination and half of the students are admitted through invitation. In case of similar scores in the national examination, UGM has 28 indicators to select students according to backgrounds and special talents.

The invitation system involves local high-schools, district officials, and private corporations. Each high-school can recommend up to 50,30, 15, or 5 percent of its best graduates, based on the accreditation status (i.e., schools with the higher accreditation status can recommend more students). In addition, local districts and corporations recommend the best students from their locations and provide scholarships for them. UGM makes the final decisions for admissions by applying its 28 indicators. The invitation by high-school has limitations, such as favoring top students from high-accreditation institutions, which tend to be located in Java. However, it does allow UGM to reach out to all accredited schools across the archipelago and select students who would have not perhaps entered based on their national exam scores. To fill the possible gap in incoming students' scholastic preparation, UGM provides the so-called 
matrikulasi or "bridge program," which helps students understand academic requirements and strengthen competency in their field of study. During their freshman year, participants must complete the 3-6 month program in order to continue their degree.

Despite the various and persistent forms of affirmative action, UGM students coming from outside Java are underrepresented, According to the 2010 national census, residents in Java equal to 58 percent, while UGM undergraduate students from Java equal to 83 percent. Although UGM students from outside Java are a minority, they are more numerous than in other universities and they impact the overall students' development. Foreign students are also encouraged to join UGM international degrees in English or regular degrees in Indonesian language; they pay higher tuitions and are accepted in the "right" number in order to leave “enough" space for Indonesian students.

In terms of curriculum, UGM provides the most comprehensive list of majors in Indonesia. Courses range from intercultural communication and international politics, to indigenous psychology and Pancasila economics. In addition to the national requirements for religion, citizenship, and Indonesian language, UGM obliges students to attend classes on community service (Kuliah Kerja Nyata, KKN), Pancasila, and English language for students who have not earned a minimum of 500 points in the TOEFL exam. These three classes are respectively linked to local, national, and global values.

Among the three courses, the KKN program is highly valued for the opportunities in hands-on learning, cooperation in diverse teams, and leadership building as well as contribution to communities in need. Founded in 1971, KKN is internationally renowned and has served as example for numerous countries. Every year 7,000 UGM students move to villages for two 
months of community service. Each group collaborates on a project and consists of a faculty leader, four additional professors, and a minimum of thirty students from different disciplines. UGM provides around 200 topics for KKN projects, such as biodiversity, sustainable economy, waste management, tsunami prevention, and creating maps for the village. Each project is set up in collaboration with ministries, local governments, industries, and other universities. The community service course has also international connections, including with Australia, Czech Republic, Germany, Malaysia, and Netherlands.

The campus is alive with artistic events from various provinces, national summits on controversial topics, and international conferences. For instance, seminars discuss how local solutions (e.g., herbal medicine) and national values (e.g., Pancasila) can resolve global issues. International initiatives are contextualized, such as for the Fulbright interfaith training on LGBT issues in Yogyakarta.

Some professors challenge students' narrow views and encourage dialogue. To overcome the passive culture that students carry on from K-12 schooling, they provide incentives for class participation. Some courses are becoming more experience-based, socially active, and attentive to problem-solving. Professors conduct research projects and supervise students' theses on the intersect between local knowledge, international scholarship, and humanist values, such as the Javanese thinking about the world. Some faculty members embody the key objectives of multicultural education, including the appreciation of cultural diversity, ability to function in various cultures, and promotion of social justice. They model pluralist life choices, for instance by minimizing religious symbols, by speaking in Indonesian so that all students can understand, as well as by celebrating Christmas and Eid-Fitr with colleagues of all faiths. 
Campus life is saturated with processes of hybridization and intercultural contact is the most effective area of diversity. Although, students from outside Java are a minority, they have a substantial impact on the university atmosphere. At UGM, students experiment a greater variety of perspectives and life choices compared to other public universities and the overall society. Prior and after UGM, students rarely have the chance to build relationships with people of so many different backgrounds. Numerous testimonies voice how intercultural contact increases their college satisfaction, cultural awareness, and social self-concept as well as postgraduate aspirations. UGM is also well-known for its many student activities and organizations. Campus clubs become "second family," where members develop lifelong relationships, collaborative skills, and learning about Indonesia and the world. Students remember joining student associations in their freshmen year as "the critical point in their life," because it exposed them to situations that they had never considered before.

UGM approaches internationalization as contributing to and from global knowledge. Indonesian concepts that can be offered to the international discourse include Pancasila, the model of Yogyakartanese pluralism, local values and practices, and Indonesian views of Islam. Yet, primordial influences are not accepted unconditionally: they have to be consistent with the humanist principles of multiculturalism (2007).

The increasing international presence on campus is appreciated, because it provides wider perspectives and services for everyone, including minority students. For instance, some cafeterias are remaining open during Ramadan, in order to demonstrate that UGM takes care of its foreign community and is committed to become a global campus. International degree programs are more innovative than their domestic counterparts. They do not admit students 
based on the national examination, but on a variety of criteria. Their curriculum includes an interreligious course and interactive pedagogy. Foreign students in domestic degree programs are also free to enroll, or not, in the monoreligious class that they prefer. However, national and international standards should not limit local inclusiveness and representation within the university.

\section{Conclusion}

The case of Indonesia is an example of how universities attempt to respond to the globally dominant educational paradigm. Institutions do not absorb the neo-liberal, Western, passive and homogenizing models completely and unconditionally. Higher education adopts a hybrid approach to its purposes and provisions, by integrating grounded (i.e., local and national) and cosmopolitan (i.e., humanist and global) allegiances. Educational aims and implementations integrate primordial, national, and international characteristics. Ultimately, grounded and cosmopolitan belongings are framed in terms of and/and not either/or - they are seen as all important and complementary. Academic communities remain in search for a "special formula" that fits their context among all possible educational options. The globally dominant educational paradigm is indeed not the only one, in theory and in practice.

\section{Bibliography}

Ananta, Aris. 2013. "Changing ethnic composition: Indonesia, 2000-2010." XXVII IUSSP International Population Conference, Busan, Korea.

Aspinall, Edward. 2009. Islam and Nation: Separatist Rebellion in Aceh, Indonesia. Stanford, CA: Stanford University Press.

Buchori, Mochtar, and Abdul Malik. 2004. "The Evolution of Higher Education in Indonesia." In Asian Universities: Historical Perspectives and Contemporary Challenges, edited by Philip Altbach and Toru Umakoshi, 249-277. Baltimore, MD: Johns Hopkins University Press. 
Cummings, William, and Salman Kasenda. 1989. "The Origin of Modern Indonesian Higher Education." In From Dependence to Autonomy: The Development of Asian Universities, edited by Philip Altbach and Viswanathan Selvaratnam, 143-166. Boston, MA: Kluwer Academic.

Farrell, Joseph. 2007. "Equality of Education: A Half-Century of Comparative Evidence Seen from a New Millennium." In Comparative Education : The Dialectic of the Global and the Local, edited by Robert Arnove and Carlos Alberto Torres, 129-150. Lanham, MN: Rowman \& Littlefield.

Fox, James. 2004. "Currents in Contemporary Islam in Indonesia." Harvard Asia Vision 21, Cambridge, MA.

Harvey, Sophia Siddique. 2007. "Nomadic Trajectories: Mapping Short Film Production in Singapore." Inter-Asia Cultural Studies 8 (2):262-276.

Hawkins, John. 2007. "The Intractable Dominant Educational Paradigm." In Changing Education: Leadership, Innovation and Development in a Globalizing Asia Pacific, edited by Peter Hershock, Mark Mason and John Hawkins, 137-162. Hong Kong: Springer.

Hawkins, John. 2011. "Variations on Equity and Access in Higher Education in Asia." In Access, Equity, and Capacity in Asia-Pacific Higher Education, edited by Deane Neubauer and Yoshiro Tanaka, 22-44. New York City, NY: Palgrave Macmillan.

Hershock, Peter. 2007. "Education and Alleviating Poverty: Educating for Equity and Diversity." In Changing Education: Leadership, Innovation and Development in a Globalizing Asia Pacific, edited by Peter Hershock, Mark Mason and John Hawkins, 115-134. Hong Kong: Springer.

Hershock, Peter. 2010. "Higher education, globalization and the critical emergence of diversity." Paideusis 19 (1):29-42.

Hershock, Peter. 2012. "Mobility, Markets and Equity in Higher Education: Match or Mismatch?" In Mobility and Migration in Asian Pacific Higher Education, edited by Deane Neubauer and Kazuo Kuroda, 28-51.

Hershock, Peter, Mark Mason, and John Hawkins. 2007. Changing Education: Leadership, Innovation and Development in a Globalizing Asia Pacific. Hong Kong: Springer.

Indonesian Central Agency on Statistics. 2010. "Population Census." Badan Pusat Statistik. http://www.bps.go.id.

Kahn, Joel. 2004. "Introduction: Identities, Nations and Cosmopolitan Practice." Identities, Nations and Cosmopolitan Practice: Interrogating the Work of Pnina and Richard Werbner, Singapore.

Khoo, Gaik Cheng. 2008. "Urban Geography as Pretext: Sociocultural Landscapes of Kuala Lumpur in Independent Malaysian Films." Singapore Journal of Tropical Geography 29 (1):34-54.

Logli, Chiara. 2015. "Bhinneka Tunggal Ika (Unity in Diversity): Nationalism, ethnicity, and religion in Indonesian higher education (Ph.D. dissertation)." University of Hawaii at Manoa.

Logli, Chiara. in press. "Cultural studies in education: Filming fluid subjectivities in Indonesian universities." Pedagogy, Culture and Society. 
Mason, Mark. 2007. "Multiculturalism, Shared Values, and an Ethical Response to Globalization." In Changing Education: Leadership, Innovation and Development in a Globalizing Asia Pacific, edited by Peter Hershock, Mark Mason and John Hawkins, 93113. Hong Kong: Springer.

Neubauer, Deane. 2007. "Globalization and Education: Characteristics, Dynamics, Implications." In Changing Education: Leadership, Innovation and Development in a Globalizing Asia Pacific, edited by Peter Hershock, Mark Mason and John Hawkins, 29-62. Hong Kong: Springer.

Nilan, Pam, and Carles Feixa. 2006. Global Youth?: Hybrid Identities, Plural Worlds. London, UK: Routledge.

Nizam. 2006. "Indonesia." In Higher Education in South-East Asia, edited by UNESCO, 35-68. Bangkok, Thailand.

Ordonez, Victor. 2007. "The Changing Role of Leadership (or a Changing Leadership for a Changing World)." In Changing Education: Leadership, Innovation and Development in a Globalizing Asia Pacific, edited by Peter Hershock, Mark Mason and John Hawkins, 249-272. Hong Kong: Springer.

Parker, Lyn. 2010. "Religious Tolerance and Inter-Faith Education in Indonesia." Conference of the Asian Studies Association of Australia, Adelaide, Australia.

Rizvi , Fazal. 2007. "Rethinking Educational Aims in an Era of Globalization." In Changing Education: Leadership, Innovation and Development in a Globalizing Asia Pacific, edited by Peter Hershock, Mark Mason and John Hawkins, 63-91. Hong Kong: Springer.

Sunarto, Kamanto, Russell Heng, and Achmad Saifuddin. 2004. Multicultural Education in Indonesia and Southeast Asia: Stepping into the Unfamiliar. Depok, Indonesia: Jurnal Antropologi Indonesia. 